\title{
Affinity Purification of Bovine Antibodies to Brucella abortus Lipopolysaccharide
}

\author{
J. M. STILLER* AND K. H. NIELSEN \\ Department of Veterinary Pathology, College of Veterinary Medicine, Texas A \& M University, College \\ Station, Texas 77843
}

Received 12 July 1982/Accepted 19 October 1982

\begin{abstract}
Alkali-treated lipopolysaccharide from Brucella abortus S1119.3 coupled to agarose beads by cyanogen bromide activation resulted in an immunoadsorbent with which a large amount of $B$. abortus-specific antibodies could be purified. The method described gave alkali-treated lipopolysaccharide binding efficiencies of up to $98 \%$. There was little loss of alkali-treated lipopolysaccharide from the column after several $\mathrm{pH}$ shifts, allowing the immunoadsorbent to be regenerated and used repeatedly.
\end{abstract}

Since the advent of methods that facilitated the attachment of proteins to polysaccharides by cyanogen halides (1), a number of modifications have been described $(3,8,11)$, and numerous studies have shown that proteins can be readily and efficiently attached to various types of supports by cyanogen bromide (CNBr) activation $(3,7,10,16)$. However, the linkage of lipopolysaccharide (LPS) to a solid matrix has had limited success. Thus, in 1981, Girard and Goichot (6) attached LPS to various types of agarose beads with benzoquinone, and Fox and Hechemy (5) used epoxy to couple LPS to Sepharose. These two types of activation produced yields of agarose-bound LPS ranging from 5 to $10 \%$ and 45 to $55 \%$, respectively. The activation described here resulted in coupling yields of up to $98 \%$, depending on the type of matrix used. With the immunoadsorbent produced in this manner, relatively large quantities of immunoglobulins with antibody activity specific to Brucella abortus could be purified.

\section{MATERIAL AND METHODS}

B. abortus lipopolysaccharide. Heat-killed $B$. abortus S1119.3 (generously provided by G. M. Brown, NSVL, Animal and Plant Health Inspection Service, U.S. Department of Agriculture, Ames, Iowa) was washed in distilled water three times by centrifugation $\left(10,000 \times g\right.$ for $15 \mathrm{~min}$ at $\left.4^{\circ} \mathrm{C}\right)$ and freeze-dried. Crude LPS was extracted by the hot water-hot phenol method (2). The phenol fraction, containing the crude LPS, was treated with 3 volumes of cold methanol to which $1 \%$ methanol saturated with sodium acetate had been added. The precipitate formed after $2 \mathrm{~h}$ at $4^{\circ} \mathrm{C}$ was recovered by centrifugation. The LPS was resolubilized in distilled water by stirring overnight at $4^{\circ} \mathrm{C}$, dialyzed against distilled water, freeze-dried, and reconstituted to $10 \mathrm{mg} / \mathrm{ml}$ in distilled water. Equal volumes of LPS and $0.5 \mathrm{NaOH}$ were combined. After incubation for $1 \mathrm{~h}$ at $56^{\circ} \mathrm{C}$, the mixture was cooled to room temperature in a water bath and neutralized with 1.0 N acetic acid. The alkali-treated LPS (aLPS) was precipitated with 3 volumes of cold ethanol. The precipitate was recovered by centrifugation, reconstituted, dialyzed against distilled water, and applied to Sepharose 4B column (5 by $95 \mathrm{~cm}$; Pharmacia Fine Chemicals, Piscataway, N.J.) equilibrated in distilled water. The material eluted in the void volume was freeze-dried.

Matrix activation and coupling of aLPS. Sepharose 4B, Sepharose 4B-CL, or Sephadex G10 (Pharmacia Fine Chemicals, Piscataway, N.J.) was activated according to the method of Johnson and Garvey (1977). Briefly, $5.0 \mathrm{ml}$ of matrix was washed by suction with $300 \mathrm{ml}$ of distilled water at room temperature. After the matrix was washed, it was transferred to a beaker that contained $15 \mathrm{ml}$ of $2 \mathrm{M} \mathrm{Na}_{2} \mathrm{CO}_{3}$ and cooled to $4^{\circ} \mathrm{C}$ in an ice bath.

The remainder of this procedure, except the overnight incubation, was carried out in a well-vented fume hood.

A 2-g amount of CNBr (Sigma Chemical Co., St. Louis, Mo.) was dissolved in $5 \mathrm{ml}$ of acetonitrile ( $E$. Merck AG, Darmstadt, Germany) by swirling gently. The CNBr-acetonitrile mixture was slowly stirred into the matrix over a 2-min period with a stainless steel spatula. The mixture was then stirred for an additional $13 \mathrm{~min}$.

The gel was returned to the suction funnel and rapidly washed with $250 \mathrm{ml}$ of $0.1 \mathrm{M} \mathrm{Na}_{2} \mathrm{CO}_{3}$ (pH 9.7)$0.5 \mathrm{M} \mathrm{NaCl}$ (carbonate buffer), followed by $250 \mathrm{ml}$ of distilled water and another $250 \mathrm{ml}$ of carbonate buffer. All wash solutions were at $4^{\circ} \mathrm{C}$.

The moist gel was then transferred to a beaker that contained $34 \mathrm{mg}$ of aLPS at a concentration of 3.4 $\mathrm{mg} / \mathrm{ml}$ in the carbonate buffer. The aLPS-gel mixture was allowed to react for $2 \mathrm{~h}$ at room temperature with continuous end-over-end mixing. After the gel reacted, it was refrigerated for 20 to $72 \mathrm{~h}$.

The aLPS-coupled gel was washed with $250 \mathrm{ml}$ of 0.125 borate buffer (pH 8.8), diluted 1:20 with $0.15 \mathrm{M}$ $\mathrm{NaCl}$. This wash was collected and retained to deter- 


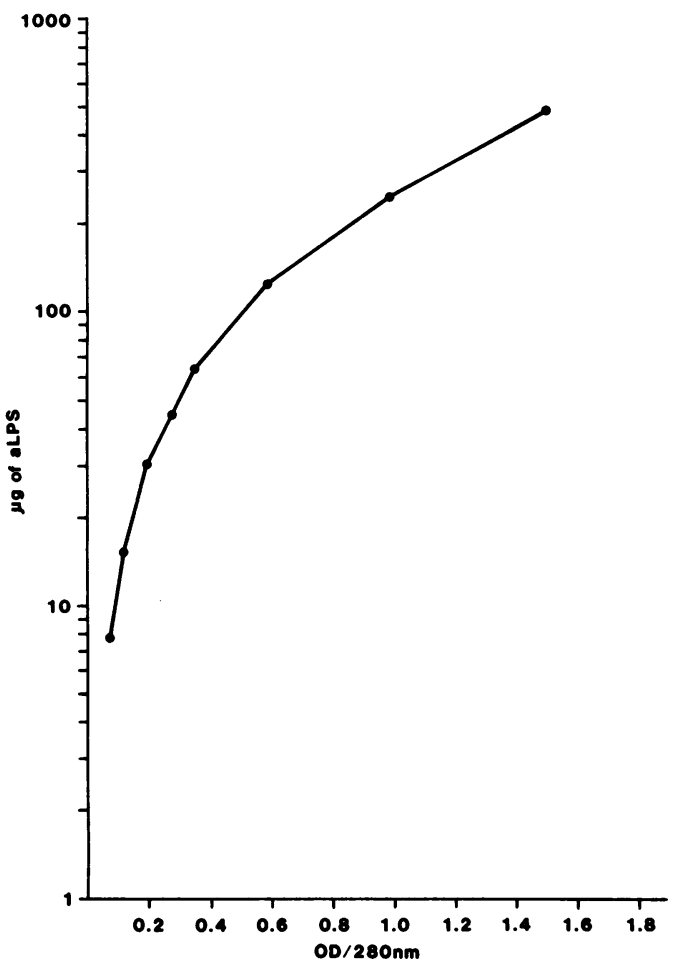

FIG. 1. Plot of OD at $280 \mathrm{~nm}(O D / 280 \mathrm{~nm})$ the concentration of aLPS from $B$. abortus $\mathbf{S 1 1 1 9 . 3}$.

mine the coupling efficiency by comparing its optical density (OD) at $280 \mathrm{~nm}$ to the initial OD of the aLPS at $280 \mathrm{~nm}$. The concentration was determined from the standard curve (see Fig. 1).

To block any remaining active groups on the matrix, we washed each gel with $50 \mathrm{ml}$ each of $0.1 \mathrm{M}$ sodium acetate (pH 4.5)-0.5 M NaCl, $2 \mathrm{M}$ urea-0.5 M NaCl and $0.1 \mathrm{M} \mathrm{Na}_{2} \mathrm{CO}_{3}$ (pH 9.7)-0.5 M NaCl. All wash solutions were at $4^{\circ} \mathrm{C}$, and washings were repeated a total of three times.

A 200-mg amount of aLPS was bound by the same procedure to $30 \mathrm{ml}$ of Sepharose 4B with proportionately larger amounts of reagents and wash solutions.

In one experiment, $5.0 \mathrm{mg}$ of aLPS was radiolabeled with ${ }^{125}$ I by the chloramine-T method (13). The specific activity was $5 \times 10^{7} \mathrm{cpm} / \mathrm{mg}$ of aLPS. The iodinated aLPS was mixed with $29 \mathrm{mg}$ of cold aLPS and bound to agarose beads as described above. The column effluent was measured for desorbed isotopes by enumeration of several representative samples in a gamma counter through $10 \mathrm{pH}$ shifts (see Table 1).

Affinity chromatography. Bovine antisera to $B$. abortus S19 were applied directly to the column (1 by $10 \mathrm{~cm})$ without prior dialysis. After the sample was applied the unbound proteins were removed with 0.1 $M$ Tris hydrochloride ( $\mathrm{pH} 7.0$ ) $-0.15 \mathrm{M} \mathrm{NaCl}-1 \mathrm{mM}$ EDTA-0.1\% $\mathrm{NaN}_{3}$ (Tris buffer) until OD at $280 \mathrm{~nm}$ became less than 0.01 . The sample application and Tris buffer were run in reverse to gravity with a peristaltic pump.

Desorption of the bound proteins was accomplished by downflowing elution with $0.2 \mathrm{M}$ glycine- $\mathrm{HCl}$ (pH 2.4)-0.1\% $\mathrm{NaN}_{3}$ (glycine buffer) until the $\mathrm{OD}$ at 280 $\mathrm{nm}$ became less than 0.01 . The protein in the glycine buffer was rapidly neutralized by the addition of Tris. The affinity column was regenerated in Tris buffer.

Both fractions were concentrated to the original serum volume either by dialysis against polyethylene glycol or by freeze-drying after dialysis against water. Antibody activity in the unabsorbed and acid-desorbed fractions was tested by slide agglutination test at a pH of 7.0 or 3.65 . Some samples were tested in an enzyme-linked immunosorbent assay and a hemolysisin-gel assay with $B$. abortus LPS as the antigen (5).

The desorbed protein fractions were tested by standard immunoelectrophoresis procedures to determine the presence of immunoglobulins that correspond to those of whole serum.

To ascertain the most suitable desorbing agent, we applied 5.0-ml samples of a bovine serum with a high titer of antibodies to $B$. abortus to the affinity column. The retained serum proteins were then desorbed with 5.0 M guanidine- $\mathrm{HCl}, 2 \mathrm{M}$ sodium iodide, $3.5 \mathrm{M}$ potassium thiocyanate, saturated $\mathrm{NaCl}$, or $0.2 \mathrm{M}$ glycine- $\mathrm{HCl}$ ( $\mathrm{pH}$ 2.4). All protein-containing fractions from each eluant were pooled, dialyzed against distilled water, and freeze-dried. After freeze-drying, the fractions were weighed, and the antibody activity was compared with that in the original serum by a tube agglutination test with doubling dilutions and by a hemolysis-in-gel assay for antibodies to $B$. abortus (K. H. Nielsen, F. C. Heck, J. M. Stiller, and B. Rosenbaum, Res. Vet. Sci., (submitted for publication).

\section{RESULTS}

Binding efficiency. When aLPS was incubated with a CNBr-activated matrix, the unbound aLPS was washed off. The wash was collected and assayed for OD at $280 \mathrm{~nm}$ to determine the amount of aLPS it contained, as compared with the standard curve (Fig. 1). By this method, it was determined that approximately 95 to $98 \%$ of the aLPS was bound to Sepharose 4B, 63\% was bound to Sepharose 4B-CL, and $10 \%$ was bound to Sephadex G10.

Subsequent use of ${ }^{125}$ I-labeled aLPS showed that the aLPS was bound to the gel, and $98.4 \%$ remained bound through $10 \mathrm{pH}$ shifts (Table 1).

Immunoadsorbent capacity. The binding activity of immunoadsorbent in the $30-\mathrm{ml}$ column was determined by applying high-titer immune sera to the column until the antibody activity could be observed in the Tris buffer. The column was washed with Tris buffer until the OD became less than 0.01 . The bound proteins were then eluted with glycine buffer. This fraction was neutralized and dialyzed against distilled water for $72 \mathrm{~h}$ and freeze-dried. By weighing the acid desorbed protein, we were able to determine that the binding capacity of immunoadsorbent ranged from 0.5 to $1 \mathrm{mg}$ of antibody per $\mathrm{mg}$ of attached aLPS. The immunoadsorbent has now been used on a continuous basis for 6 months.

The use of smaller serum samples readily 
TABLE 1. Elution of ${ }^{125}$ I-labeled $B$. abortus S1119.3 aLPS after CNBr linkage to Sepharose 4B with $10 \mathrm{ml}$ of glycine buffer (pH 2.4) and $10 \mathrm{ml}$ of Tris buffer (pH 7.0).

\begin{tabular}{cc}
$\begin{array}{c}\text { pH } \\
\text { shift }^{a}\end{array}$ & $\begin{array}{c}\text { \% Loss of } \\
\text { isotope }^{b}\end{array}$ \\
\hline 1 & 0.17 \\
2 & 0.36 \\
3 & 0.26 \\
4 & 0.15 \\
5 & 0.09 \\
6 & 0.07 \\
7 & 0.16 \\
8 & 0.14 \\
9 & 0.11 \\
10 & 0.10 \\
\hline
\end{tabular}

a There was an overnight break between pH shift 5 and $\mathrm{pH}$ shift 6.

${ }^{b}$ Percent loss of isotope was calculated on the basis of the total counts per minute in $20 \mathrm{ml}$ of column effluent, with total counts per minute incorporated into the column $\left(2.47 \times 10^{8} \mathrm{cpm}\right)$. The total percent loss of isotope over $10 \mathrm{pH}$ shifts was $1.6 \%$.

demonstrated that unattached proteins were not capable of agglutinating $B$. abortus, whereas the acid-desorbed proteins, once neutralized, were fully capable of agglutinating $B$. abortus. The application of affinity-purified antibodies to $B$. abortus aLPS in the enzyme-linked immunosorbent assay and the hemolysis-in-gel assay has been described (K. H. Nielsen, et al., submitted for publication). The acid-desorbed antibody molecules had characteristics commonly observed for bovine immunoglobulins (4).

\section{DISCUSSION}

The relatively low yield of agarose-bound LPS has prevented a large-scale isolation of affinity- purified antibodies $(5,6)$. The application of acetonitrile-activated $\mathrm{CNBr}(8)$ to agarose beads can overcome this difficulty, producing an efficiency of binding of $B$. abortus aLPS of up to $98 \%$. Based on the attachment of ${ }^{125}$-I-labeled $B$. abortus aLPS, the covalent bonds of $\mathrm{CNBr}$ to the agarose are not readily destroyed by the $\mathrm{pH}$ shift frequently used to desorb antibodies from the affinity column. Thus during $10 \mathrm{pH}$ shifts, $1.6 \%$ of the radioactivity was eluted from the affinity column (Table 1). Recovery of adsorbed antibodies and the maintenance of biological activity in terms of agglutination titer, particularly with regard to complement fixation capacity, appeared most efficient with $0.2 \mathrm{M}$ glycine$\mathrm{HCl}$ ( $\mathrm{pH} \mathrm{2.4)}$ (Table 2). The aLPS contained approximately $10 \%$ protein, which appeared to be covalently bound to the LPS, as extensive purification procedures failed to reduce this protein component to below $6.3 \%$ (14). In addition, the presence of other antigens, although minor, cannot be excluded. These impurities, if conjugated to the matrix, may result in antibodies with activity to antigens other than LPS that are eluted from the columns.

The use of affinity-purified antibodies has farreaching potential for the standardization of serological procedures and for the study of diseases such as brucellosis. It is possible to purify milligram quantities of specific antibodies that may subsequently be separated into isotypes (also by affinity chromatography). These isotypes in turn can be used to firmly establish the sequence of antibody isotype production in the infected host. This information is very useful for determining the serological tests required for screening and for confirmatory tests. Butler et al. (J. E. Butler, G. I. Seawright, P. L. McGivern, and M. Glsdorf, in J. E. Butler, ed., The Ruminant Immune System, p. 790, 1981) has elegantly demonstrated with an isotype-specific

TABLE 2. Concentration and antibody activity of proteins from $5.0 \mathrm{ml}$ of bovine serum desorbed by various chemicals from a $B$. abortus aLPS affinity column

\begin{tabular}{lccc}
\hline \multicolumn{1}{c}{ Desorption medium } & $\begin{array}{c}\text { Protein } \\
\text { recovered } \\
(\mathrm{mg})\end{array}$ & \multicolumn{2}{c}{ Biological activity } \\
\cline { 3 - 4 } & & $\begin{array}{c}\text { Serum } \\
\text { agglutination } \\
\text { titer }^{a}\end{array}$ & $\begin{array}{c}\text { Hemolysis-in- } \\
\text { gel }^{\text {assay }}\end{array}$ \\
\hline 5.0 M Guanidine-HCl & $88.5^{c}$ & 1,280 & 0 \\
3.5 M KSCN & $58.2^{c}$ & 640 & 0 \\
2.0 M NaI & 23.4 & 650 & 8.0 \\
O.2 M Glycine-HCl (pH 2.4) & 37.3 & 2,560 & 13.0 \\
Saturated NaCl & 12.2 & 40 & 0 \\
Original serum & NA $^{d}$ & 2,560 & 14.0 \\
\hline
\end{tabular}

a Expressed as the reciprocal of the highest dilution that agglutinated $50 \%$ of the antigen.

$b$ Expressed as the diameter (in millimeters) of the zone of hemolysis with each sample diluted 1:1 with fresh bovine serum serologically negative for $B$. abortus.

$c$ Partly insoluble when reconstituted with phosphate-buffered saline to the original serum volume ( $5 \mathrm{ml})$.

d NA, Not applicable. 
enzyme-linked immunosorbent assay that immunoglobulin $\mathbf{G 1}$ is the more important antibody isotype in bovine brucellosis. However, Rice et al. (15) and Jones (9) have published evidence that the immunoglobulin $M$ class of antibodies is important in the early stages of infection. Immunoglobulin $\mathbf{M}$ antibodies to $B$. abortus are not readily measured in an enzymelinked immunosorbent assay (12). Therefore, affinity-purified antibodies of the various bovine isotypes would be very useful not only in establishing the test(s) and the parameters necessary for their measurement but also in the continuous standardization of the tests and in the determination of test sensitivity and specificity.

\section{ACKNOWLEDGMENTS}

This project was funded by Texas Agricultural Experiment Station grant TAES H-6194 and U.S. Department of Agriculture grant USDA/SEA/AR 58-519B-0-880. The authors wish to thank Ms. L. Sroufe and Ms. J. Hernandez for their patience in typing this manuscript.

\section{LITERATURE CITED}

1. Axen, J. R., J. Porath, and S. Ernbeck. 1967. Chemical coupling of peptides and proteins to polysaccharides by means of cyanogen halides. Nature (London). 214:13021304 .

2. Baker, P. J., and J. B. Wilson. 1965. Hypoferremia in mice and its application to the bioassay of endotoxin. $J$. Bacteriol. 92:1298-1303.

3. Cuatrecasas, P. 1970. Protein purification by affinity chromatography. J. Biol. Chem. 245:3059-3065.

4. Duncan, J. R., B. N. Wilkie, F. Hiestand, and A. J. Winter. 1972. The serum and secretory immunoglobulins of cattle: characterization and quantitation. J. Immunol. 108:965-976.
5. Fox, J., and K. Hechemy. 1978. Coupling of Escherichia coli lipopolysaccharide to epoxy-activated Sepharose 6B. Infect. Immun. 20:867-868.

6. Girard, R., and J. Goichot. 1981. Preparation of monospecific anti-Salmonella lipopolysaccharide antibody by affinity chromatography. Ann. Immunol. 132C:211-217.

7. Hofmann, K., and Y. Kiso. 1976. An approach to the targeted attachment of peptides and proteins to solids supports. Proc. Natl. Acad. Sci. U.S.A. 73:3516-3518.

8. Johnson, G., and J. Garvey. 1977. Improved methods for separation and purification by affinity chromatography. $\mathrm{J}$. Immunol. Methods 15:29-37.

9. Jones, L. M. 1977. Brucella antigens and serologic test results, p. 40-48. In R. P. Crawford and R. J. Hidalgo (ed.), Bovine, brucellosis. Texas A \& M University Press, College Station, Tex.

10. Kagedal, L., and S. Akerstrom. 1971. Binding of covalent proteins to polysaccharides by cyanogen bromide and organic cyanates. I. Preparation of soluble glycine-, insulin- and ampicillin-dextran. Acta Chem. Scand. 25:18551859.

11. Kumel, G., H. Daus, and H. Mauch. 1979. Improved method for the cyanogen bromide activation of agarose beads. J. Chromatogr. 172:221-226.

12. Lamb, V. L., L. M. Jones, G. G. Schurig, and D. T. Berman. 1979. Enzyme-linked immunosorbent assay for bovine immunoglobulin subclass-specific response to $\mathrm{Bru}$ cella abortus lipopolysaccharides. Infect. Immun. 26:240 247.

13. McConahey, P. J., and F. J. Dixon. 1966. A method of trace iodination of proteins for immunologic studies. Int. Arch. Allergy Appl. Immunol. 29:185-195.

14. Moreno, E., D. T. Berman, and L. A. Boettcher. 1981. Biological activities of Brucella abortus lipopolysaccharides. Infect. Immun. 31:362-370.

15. Rice, C. E., J. Tailyour, and D. Cochrane. 1966. Ultracentrifugal studies of sera from cattle vaccinated or naturally infected with Brucella abortus. Can. J. Comp. Med. 30:270-278.

16. Van Ejik, H. G., and W. L. Van Noort. 1976. Isolation of rat transferrin using CNBr-activated Sepharose 4B. J. Clin. Chem. Clin. Biochem. 14:475-478. 